\title{
The public sphere and Muslim identities
}

W A S H I N G T O N policy makers acknowledged a new sense of public in the Muslim-majority and Arab worlds even before the September I I, $200 \mathrm{I}$ terrorist attacks. For them, it is called the 'Arab street',

a new phenomenon of public accountability, which we have seldom had to factor into our projections of Arab behavior in the past. The information revolution, and particularly the daily dose of uncensored television coming out of local TV stations like al-Jazira and international coverage by $\mathrm{CNN}$ and others, is shaping public opinion, which, in turn, is pushing Arab governments to respond. We don't know, and the leaders themselves don't know, how that pressure will impact on Arab policy in the future (Walker 200I; see also Tenet 200I).

The use of the term 'street', rather than 'public sphere' or 'public', imputes passivity or a propensity to easy manipulation and implies a lack of formal or informal leadership. Nonetheless, this use of 'street' shows how policy makers now acknowledge that authoritarian and single-party states also have 'publics' that they must take into account.

\section{Political 'belonging' in precolonial Morocco}

The idea of the 'street' or the 'public sphere' is not recent for the Arab or the Muslim-majority world. Consider, for example, the oath of allegiance $\left(b^{\prime} y^{\prime} a\right)$ to the ruler in precolonial Morocco. Political 'belonging' was not based on unquestioned belief, but on a continuing process of contest and reaffirmation. Since at least the fifteenth century, Moroccan monarchs circulated almost continuously throughout their domains. In royal progresses (harkas) with their entourage, they embod-

An earlier version of this paper was presented at the European-American Young Scholars' Summer Institute, 'Public Spheres and Muslim Societies', held July $200 \mathrm{I}$ in Berlin and funded by the Alexander von Humboldt Foundation. The authors wish to thank its participants for their comments and suggestions.

92

Dale F. Eickelman, Dartmouth College (Hanover, NH).

Armando SalvatoRe, Humboldt University (Berlin).

Arch.europ. sociol., XLIII, I (2002), 92-1 I 5-0003-9756/00/0000-738\$07.50 per art + \$o. Io per page (C) 2002 A.E.S. 
ied their personal authority in constantly shifting locales, including the four imperial cities of Fez, Marrakesh, Meknes and Rabat (Geertz I 983: I $36-$ - 37 ).

The legal and popular dimensions of the bay' $a$ shed light on the nature of Morocco's precolonial public. Bettina Dennerlein (200 I : 2873 10), for example, discusses the October i 873 oath of allegiance in Fez to Sultan Mawlay al-Hasan. The artisans of Fez insisted on making the $b^{\prime} y^{\prime} a$ contingent on the abolition of certain non-Islamic taxes. The men of learning ('ulama) and others who drew up the bay' $a$ (notables and military leaders) agreed to this provision, although a few days later 'certain people' nonetheless prepared to reinstate the tax. Learning of this development, the tanners of Fez and their followers attacked and plundered the residence of the tax administrator, who took refuge with his family in the shrine of Mawlay Idris, the patron saint of Fez.

A month later, Mawlay al-Hasan announced an amnesty for those involved. When the sultan himself arrived in Fez in April i 884, however, he ordered the non-Islamic taxes restored. Again conflict erupted. This time the royal army besieged the rebellious quarters, killing and pillaging until the inhabitants again accepted the same taxes as had been levied under the ruler's father and predecessor, Mawlay Muhammad ibn 'Abdarrahman.

The bay' $a$ documents that Dennerlein analyzes indicate the contingent nature of collective identities. Kinship, social status, locality and occupation were all 'possible organizing principles for the construction of political belonging'. An important element in achieving notable status was the ability-whether as judge, military leader, descendant of the Prophet (sharif), head of a guild of merchants or artisans, or tribal leader - to secure loyalty and obedience to the ruler. Bay' $a$ documents were read aloud in public in every town in which they were prepared, generally in mosques. Some represented collectivities, others prominent notables, and the texts of various bay' $a$ s were circulated throughout the monarchy.

The specifics of these texts varied, but the standard components included elements affirming the ruler's legitimacy and at least implicitly limiting him to rule according to the precepts of Islamic law and 'generally accepted standards of how a ruler should act' (Dennerlein 200 I: 309). A second element venerated the descendants of the Prophet Muhammad, the shurafa. As Dennerlein concludes, the bay' $a$ 'obviously did not represent a contract freely agreed upon between equal parties and creating mutually binding, immediately obtainable rights and obligations'. Neither, however, did it merely justify autocratic rule by the 
sultan. Its significance 'lay in its contribution to sustaining and acting out a sense of political belonging'. Recognition of the ruler was 'rather the result of a combination of different forms and different levels of empirical involvement of individual and collective actors with a particular discourse on political ruler in Islam'. Religious discourse was rarely used to delegitimize a particular ruler, but it 'nevertheless created a certain space for debate'. It also indicates that the various social actors were 'actively' involved in sustaining the sense of political community (Dennerlein 200 I : 3 Io).

The practical workings of the precolonial bay' $a$ in Morocco point to the existence of a pre-modern public sphere, offering a wide-ranging flow of discursive social action. In this public sphere, members of the social body monitored one another and acted through a combination of at least partial consensus and a shared hierarchy of leaders of influence. There were some formalized institutional arrangements, such as pious endowments (awqaf), but informal and pervasive patterns of influence, responsibility, and shared expectations were equally important. These arrangements offered a framework for discourse and practice that extended beyond households, villages and immediate localities, facilitating discussions of the common good and of shifting, continually contested, boundaries of inclusion and exclusion.

The public sphere is thus not limited to 'modern' societies. It is the site where contests take place over the definition of the 'common good', and also of the virtues, obligations and rights that members of society require for the common good to be realized. This emergent sense of public goes hand-in-hand with the sharing of norms that define ideas of community and the responsibilities of those who belong to it. The idea of the public sphere is thus a wider notion than that of civil society. As Kamali (200 I: 458) observes, 'Although there is no consensus about the definition of civil society, there are some factors, such as individualism and democratic institutions, that are taken for granted as necessary conditions'. But he also notes that individualism and democratic institutions are not necessary for a civil society to exist. One of the preconditions for civil society, however, is the 'existence of a relatively independent public sphere' in which debate takes place that 'influences' political decision-making. It is useful to recall the argument put forward by Richard Tapper ( I 990) over a decade ago, that 'tribal' regions of the Middle East, rather than being regions of necessary disorder and anarchy, often offered more opportunities for peace and a 'just' social order than those available through submission to state authorities. In this sense, tribal orders have sometimes offered the prospects of civil society 
in the sense of the emergence of institutions autonomous from the state that facilitate orderly economic, social and political activity and that imply a moral order largely distinct from state or royal authority. The more common, narrow usage of civil society, especially since the early I 990 , has been the promotion of non-governmental organizations, human rights, and honest elections. This narrower sense of civil society is an important one, but again presupposes the existence of a 'relatively independent public sphere'.

In claiming that the $b a y^{\prime} a$ in precolonial Morocco suggests the existence of a public sphere, we encounter a limitation that is still at the core of much current social theory. In spite of the fact that several historical and anthropological works on Africa and Asia have shown the elements of transaction and legitimacy present in clan, lineage and tribally-based collectivities, social theory still foregrounds developments in Europe to the detriment of other world regions (see Chakrabarti 2000: 3-6). In the introduction to his sociology of religion, Max Weber (I920: I) stated that his interest was to explain the combination of factors that resulted in European uniqueness. Later scholars were less cautious. They used European institutions as the comparative basis against which to measure social and cultural institutions elsewhere.

Even if not intending to create a yardstick for interregional comparison, Jürgen Habermas, whose name is closely associated with the idea of the public sphere, sees as its essential element the historical emergence in Europe of 'rational-critical' discourse among the 'reasoning public' of eighteenth century bourgeois society (Calhoun I 992: 7). The vast international echoes that Habermas' argument gained after the translation of his book into English and the fall of the Soviet Union have made his argument on the public sphere an equally powerful token of Eurocentrism in social theory.

\section{The public sphere: beyond Europe and before modernity}

At its base, Habermas' idea of the public sphere implies a space separate from the formal structure of political authority and the space of households, kin, and, later, the European 'nuclear' family. Habermas defines the public sphere as 'a realm of our social life in which something approaching public opinion can be formed. Access is guaranteed to all citizens. A portion of the public sphere comes into being in every conversation in which private citizens assemble to form a public body' 
(Habermas 2001 [orig. 1989]: I02-103). In a notion that can be traced back to Immanuel Kant ( $1724-1804)$, the public sphere for Habermas is ideally an intermediate space in which ideas are presented on their own merits rather than as emanating from such authorities as preachers, judges and rulers. Authority is vested in the public sphere itself. In it, all participants have in principle an equal opportunity to persuade others.

Even for early modern Europe, however, the early Habermas neglected the role of religion in the development and expansion of the public sphere. For example, he ignored the movements of pietism and religious revivalism that were so successful in different parts of Germany, including Prussia, as well as in Scandinavia and other Protestant majority parts of Western Europe. These movements instituted a sense of legitimacy through congregational forms of deliberation, as opposed to the dominant state-bound Lutheran churches. In later writings, Habermas acknowledged that the process through which norms are produced, which reflect general interest and create an 'overlapping consensus' in society, can only be rooted in tradition, familiarity and culture, through which individuals internalize the procedures of consensus. This also applies to 'those who do not belong to the lucky heritage of Jefferson'. The communicative presuppositions for generating such a consensus are not the privilege of a particular culture (Habermas I992: 84-86).

In emphasizing the 'rationality potential' of communicative action rooted in the 'life world' as the generating source for shared notions of justice, Habermas (1 992: 62-77) in his more recent writings has made a major contribution in showing that there is no inherent reason why the notion of public sphere has to be restricted to an idealized European bourgeoisie. Building on the later Habermas in discussing the eighteenth century and later periods, Casanova (1994: 56) reminds us of the 'public and political posture of free, congregational, "leveling", nonconformist sects or of any disestablished religion ready to clash with an unjust and sinful state'.

Although the complex relationship of the Enlightenment to movements of religious renewal was known to European thinkers before Habermas, and has been increasingly evidenced by historians after the translation of Habermas' main work into English (Salvatore 1997: 26), prevailing theories of modernity and modernization in the midtwentieth century assumed that religious movements, identities and practices had become increasingly marginal to modern societies. These conventional assumptions have also until recently blocked the search for distinctive public spheres in 'traditional' societies in general and 'Mus- 
lim' societies in particular. Ernest Gellner (I994: 2 I I), for example, regarded Islam as imposing 'essential' constraints on the conduct and thought of those committed to it. Similarly, consolidated frames of interpretation of the evolution of the Ottoman Empire discouraged consideration of continuities between the religiously legitimated empire and the ensuing secular republic. New approaches to social, political and economic history point instead to how the Ottoman Empire initiated many of the underlying developments of modern Turkish society, including changing notions of belonging, land and territory. Modernity as a process antedated the republican era (Meeker 2002; Duben and Behar I99I).

\section{Discerning the public}

In The Public and Its Problems (1927), John Dewey (I859-I952) argues that in no two ages or places does the same idea of the public exist. By 'public', Dewey means an institution with recognized common goals and at least an informal leadership, so his notion coincides with Habermas' concept of the public sphere. Dewey ( 1927: 33) writes 'What the public may be, what the officials are, and how adequately they perform their functions, are things we have to go to history to discover'. When acting in the public interest, people behave neither like business or professional people transacting private affairs, nor like members of a constitutional order subject to the legal constraints. The state is part of this public insofar as it is seen as legitimately representing the interests of the community. The public is 'organized and made effective by means of representatives who as guardians of custom, as legislators, as executives, judges, etc., care for its especial interests by methods intended to regulate the conjoint actions of individuals and groups. Then and in so far, association adds to itself political organization' (Dewey i 927: 35). Dewey reaffirms the necessary role of intermediary institutions and authorities, as against the emphasis that Kant and Habermas place on the public sphere occupying a social space freed from the influence of such authorities.

Dewey's approach also offers an alternative to treating history in monolithic 'chunks' such as 'Pre-Axial/Agrarian', 'Axial', and 'Modern', categories that inadvertently deflect attention away from how societies change. Political forms for Dewey develop incrementally through 'the outcome of a vast series of adaptations and responsive accommodations, 
each to its own particular situation' (Dewey I927: 84). Dewey also cautioned against the idea of technology itself structuring culture. The invention of the printing press, for example, did not inevitably lead to democracy (Dewey I 927: I IO). Yet at the same time, inventions such as the electric light bulb contributed vastly to restructuring the use of space and time, just as television has been crucial in constructing the leisure time of privatized and passive late twentieth century consumers. For Dewey, writing in the aftermath of World War I, the great transformation was the 'machine age', which had 'so enormously expanded, multiplied, intensified and complicated the scope of the indirect consequences' of vast, impersonal economic and political actions. The result is too many 'inchoate, conflicting, and uninformed' publics, whose common interests are difficult to discern and construct (Dewey I 927: I 26, I 3 I).

If a sense of public, including 'local communal life', can be established in the modern 'machine age', Dewey argued, then 'it will manifest a fullness, variety and freedom of possession and enjoyment of meanings and goods unknown in the contiguous associations of the past'. It will be 'alive and flexible as well as stable, responsive to the complex and world-wide scene in which it is enmeshed' (Dewey I927: 2 I6). In contrast to Habermas' pessimistic view of modern social forms, Dewey emphasizes modernity's potential. 'The observation that the interests of the community are better cared for when there is permitted a large measure of personal judgment and choice in the formation of intellectual conclusions, is an observation which could hardly have been made until social mobility and heterogeneity had brought about initiation and invention in technological matters and industry, and until secular pursuits had become formidable rivals to church and state' (Dewey 1927: 50).

Dewey's formulation of the public is more open and flexible than that of Habermas and thus can be applied to more historical contexts. Habermas himself has cautiously and indirectly recognized the value of Dewey's non-Kantian approach (Habermas I 992: 2 I I). Dewey highlights the features of 'modern' society - for Dewey, the 'machine age' of the I 920 - that distinguish it from earlier eras. At the same time, Dewey eschews the attribution of public to merely one type of society or historical era. He emphasizes the vast number of practices, habits and responsive adjustments to different situations that contribute to shaping a sense of public based on overlapping interests.

The development of mass higher education in Muslim majority societies since mid-century (Eickelman r992) and, more recently, 
increasingly accessible forms of communication and new media have played a significant role in fragmenting and contesting political and religious authority (Eickelman and Anderson i999: I-I 8). But these recent developments did not call a public sphere into being. Instead, they contributed significantly to reshaping a sense and structure of public that was already available. The intensified fragmentation of religious and political authority characteristic of the modern era does not lead inevitably to democracy or 'civil society', but the transparency that recent developments-including rapid communications by telephone, fax, internet, and a greater ease in travel-make possible obliges even the most authoritarian of regimes to justify their actions. It also increases the scope, intensity, and forms of involvement in a multiplicity of overlapping public spheres. Human rights organizations, NGOs, women's rights groups, and religious organizations, among others, can operate more quickly and independently across national and regional boundaries in modern conditions. Actors in a repressive 'homeland' public sphere can also enter more readily into contact with their 'diaspora' counterparts, often living in circumstances less subject to political control and intimidation.

The increased possibilities for transnational communication also contribute significantly to widening 'homeland' public spheres. Some ideas of public can be intensely local; others can be transregional and transnational, expressing multiple ideas of group and community. Participation in the contemporary public sphere implies an openness and at least implicit pluralism in the sense of a capacity to act-or at least express beliefs-independently from state or ruling authorities.

\section{Islam in the public sphere: linking past and present}

The significance of informal ties in creating a vital public sphere becomes more salient when we focus on accepted and socially legitimated means of accomplishing a task, rather than just on formal institutions authorized or acknowledged by some authority or ruler. These background clusters of concepts, shared understandings, and practices underpin the public sphere in any historical era (Taylor I993: 213). Guilds of merchants and craftsmen, although recognized by the Ottoman administration, operated in an autonomous manner, punishing infractions by their members, defining acceptable practice, and settling disputes. Pious foundations (awqaf) enjoyed a similar autonomy. 
Due to their informal organizational character, Sufi orders, or religious brotherhoods offer an excellent locus for understanding historical shifts in the public sphere in Muslim majority societies. In recent centuries these developments have become increasingly entangled with European ones, although they do not necessarily follow the same trajectory.

Although informal, the ties between master and disciple in Sufism have a substance and concreteness as significant as such formal and legally recognized institutions as guilds, pious endowments (waqfs) and mosque-universities (madrasas). Acknowledging the change in political forms over time, anthropologist Abdellah Hammoudi ( I 997) argues that the master-student tie in Sufism serves as the key metaphor and practice by which authority is legitimated throughout the Arab world in general, and Morocco in particular, notwithstanding the formal trappings of parliamentary and other representative institutions since independence.

Hammoudi's argument can be criticized for imputing to earlier historical contexts the social relationships of later periods. However, other historians show how many Sufi orders shifted in the eighteenth century toward more formal and hierarchical organization. This shift allowed some orders to serve as vehicles for social and political change (Levtzion 2002). In some cases the authority of the shaykh expanded beyond the narrow range of both the madrasa and the tariqa (brotherhood) and became a vehicle for internalizing Islamic norms in the wider society. Dealing with the early nineteenth century Sudan, Hofheinz ( I 992-I 993) has pointed out how religious specialists with a high degree of formal schooling worked to spread the norms of scriptural Islam among the illiterate population of smaller towns and the countryside, as opposed to forming a more aloof scholarly or mystical elite. In a manner comparable to the Pietistic missions in the countryside in central and northern Europe, these movements inculcated the know-how needed to adapt emotionally and structurally to the wider socio-political transformations taking place as part of incorporation into the colonial system and the slow formation of nation-states. These transformations are what Elias called the 'civilizing process'. They consisted of the formation among wide sectors of the population of more or less uniform norms that helped anticipate the consequence of one's behavior in wider society, and therefore created a sense of public interest.

In a similar vein, Sufi leaders and orders in Algeria, long discredited because of their reputation for compromise with French colonial authorities, reemerged in the I 980 os together with Islamic associations as a backbone for collective action independent from both Islamic extrem- 
ists and the state (Rouadjia I 990: 34, 59, 74, I I I Andezian 200 I : 76-78, 86-88). As in the example of the Sudan in the nineteenth century, Sufism offered a template-as did other forms of religious association-for developing norms and expectations that encompassed social life in general and not just that of the religious order alone.

The common element between Sufi organizations in earlier eras and in the present is the tenacity of the master-disciple relationship and its potential for legitimating various forms of religious and political authority. Sufi orders reached out to a variety of constituencies, using not only madrasa Arabic but also its colloquial counterparts and the vernacular languages of different regions. Ruling authorities were often deeply suspicious of the orders because of their autonomy and capacity for independent action, linking the local with much wider spheres of influence. In fifteenth century Morocco, for example, saints or 'pious ones' (salihun) manifested not only a closeness to the Divine presence (walaya) but also exercised worldly authority (wilaya) (Cornell r 998). Saints embodied a just moral order. Both in practice (for living saints were prominent in North Africa as elsewhere) and as cultural metaphors, saints set limits to the abuse of authority and contributed to the creation of Morocco's political order.

More generally, the innovative Sufi movements of the seventeenth, eighteenth and nineteenth centuries in many parts of the Muslim world, from the Maghrib to South and Southeast Asia, interpreted texts and practices far beyond the narrower compass offered by scripture-and law-based religious scholarship. Sufi practices in this period increasingly favored understandings that were less oriented to the esoteric and mystical than to inculcating collective understandings and shared practices that could cut across lines of occupation, wealth, lineage and region. These notions were still ambiguously poised between the disciplines of mystical self-denial and a more socially oriented disciplined participation in society (Gran I979: 42-49; Salvatore I997: 4I-48). Still, these shared habits and practices contributed significantly to developing Islam as a principle of the social order.

Sufi 'revivalism' in the last three centuries paved the way for a new conception of Islamically legitimated action in public life by implicitly developing the idea of the social Muslim. Sufism asserted the right of individual believers to experiment with the 'truth' independent of the

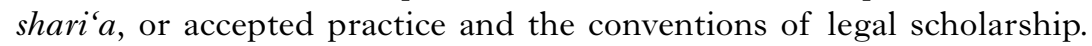
Sufi orders, often interconnected over large distances, were usually not directly political but offered a template for intervention in society independent from both the state and from local affinities such as tribe, vil- 
lage or region (Reichmuth 2000). These orders often offered a secure social role and engendered a strong sense of interdependence. Several revivalist movements in North and West Africa even led to the foundation of new forms of political domination, including Sufi and Mahdist movements in Cyrenaica, Sudan, and Nigeria (Keddie I 994; Reichmuth I996). These movements became increasingly active in politicssometimes within major centers of learning and sometimes challenging the established order. The neo-Sufi movements often grew in response to European political and economic domination, but responded equally to local developments.

Parallel to the emerging sense of social Islam engendered through Sufi orders by the eighteenth century, religious scholars and the general public alike increasingly began to see the shari' $a$ as more than a specialized juridical-theological notion. The spread of printing, in particular, accelerated the standardization of texts (Robinson I 993). It also encouraged making the shari' $a$ a popular trope rather than just a jurist's notion, encompassing the explicit and implicit, taken-for-granted rules, habits and practices needed to live a good life as a Muslim. In Egypt, for example, by the late nineteenth century the concept of shari' $a$ took on a new meaning as a template for reasonable, just and expected social practice-in short, social normativity. In this sense, it acquired a meaning distinct from the concrete law applied by the courts and from the science of jurisprudence (fiqh) charged with making sense of it (Salvatore 2000). This discourse was illustrated and propagated by the rise of a print culture that increasingly incorporated issues of economic prosperity and its associated social and moral requirements into the public virtues of faith (Gasper 200I).

\section{The emerging public sphere in Muslim majority societies}

Even in societies where religious expression and practice are strongly regulated or circumscribed in the public sphere, such as constitutionally secular Turkey and Ba'thist Syria, they serve as an important element of the background understandings for most members of society. Adapting such understandings to current social practice, Egypt's Muslim Brotherhood movement (al-ikhwan al-muslimun) emerged in the I 920 s to become what many observers still consider as the only genuinely popular mass political movement in twentieth-century Egypt, reaching its heyday after the Israeli defeat of the combined Arab states in I 948. Royalist 
Egypt allegedly saw the movement as a sufficiently serious political threat to organize the assassination of its leader, Hasan al-Banna', in I949. Two years after the 1952 Egyptian revolution, Nasser ruthlessly suppressed the movement for the same reason. Again in 2002, the Egyptian state is indicting the movement as a threat to state security in spite of prior tacit approval for some of its key figures to participate in parliament.

The proliferating efforts of thinkers, associations and social movements trying to discern how to lead a good 'Muslim' life under modern conditions have been particularly vigorous since the late I920s. This is when movements like Egypt's Muslim Brotherhood tried to make Islam fit the requirements of social development under the conditions of modern nation-state building. More recently, the crisis of secular nationalism since the late i 960 s and the r 970 s has created favorable conditions for a religiously oriented reflection and mobilization that integrates individual salvation and self-realization with a commitment to community welfare. Of course, as indicated earlier, rising levels of education, the proliferation of ready forms of communication, and greater ease of travel have accelerated this process. Not only new communicative technologies, but also new uses of such humble elements of local communication as the telephone to enable women to participate in political and social movements, as in Istanbul (White I 999), have facilitated broader participation in community activities.

The Egyptian Muslim Brotherhood was well organized for gaining popular support in an earlier era and served as a model for similar movements elsewhere. It retains a strong hold in Egypt. However, popular political and religious movements of more recent origin, including Lebanon's Hizbullah, Palestine's Hamas, and-for the sake of a non-Islamic comparison-Israel's Shas have adapted themselves to play a role in their respective public spheres. It is easy to think of such movements primarily in terms of their political influence. At their base, however, they appeal to their respective constituencies through their implicit and explicit invocation of shared moral understandings of social action. In the case of the two Arab groups, the social base includes a primary commitment to social work or action (al-iltizam bi-l-'amal al-ijtima' $i$ ). Morally- and religiously-inspired social action underlies the building of networks that provide assistance to the needy, basic health care and education-services that the state often cannot efficiently provide. Such social action can be informally organized, based on affinities of shared habits, expectations, practices and interests. It can also coalesce around formal institutions and associations. Such move- 
ments can also provide non-state forms of arbitration and justice, media representations, and formulate blueprints for the entire national polity (see Deeb, forthcoming). These associations provide dependable personal ties to cut through poorly understood bureaucratic regulations and indifferent bureaucracies. Religiously based charitable associations, focusing on a wide array of services (medical, educational, family welfare and emergency assistance), play exactly such a role. They build initially on ties of local trust (Benthall 2000: I-2) and community, although they can also provide a base for subsequent political participation.

Such forms of religiously motivated charitable and service association involve an intricate web of informational and expressive transactions (McQuail I992: 2). They remind us that the public sphere is composed of more than agents who actively participate in specific institutions or associations, although the existence of such associations is an important element of the public sphere. Other groups lack formal organization and are clustered more by affinity. This is the case for the groups and activities associated with Fethullah Gülen in Turkey, for example. They lack central organization and coordination-an asset when elements of the state become repressive and seek to seize assets and people-but their component associations and groups share a common moral orientation to action within society and polity.

An indicator of the dynamic, underlying values on which such informal and formal activities are based is the proliferation of what has been called the 'Islamic book', a style of writing that appeals to new audiences. These are inexpensive, attractively printed mass-market texts that address such practical questions as how to live as a Muslim in the modern world and the perils of neglecting Islamic obligations. Some offer advice to young women on how to live as a Muslim in modern urban society, and some take the form of popular catechisms. These books articulate basic questions bearing directly on the lives of average citizens. For example, do Islamic traditions and practices-subject to deep and traumatic strains and transformations, especially since the colonial era-still offer sure guidelines for how to conduct one's life, educate one's children, and participate in community affairs, mosque, nation, and community of Muslims worldwide? If not, how can such traditions or practices be restored or adapted to current practice?

Such 'Islamic books' break with the cadences of traditional literary Arabic (and with parallel traditions in other languages widely used by Muslims, including Bengla, Urdu, English and French) and instead are often written in a breezy, colloquial style. They are often sold on 
sidewalks and outside mosques, and since the i 970 s have eclipsed other types of books in the market (Gonzalez-Quijano I998: I7 I-I98). The more conventional sort of 'grand' intellectual discourse continues, but is often confined to narrow intellectual circles (Salvatore I 997: 2 I 9-24I). Equally pervasive are audio and video cassettes, and popular preachers who have mastered the new media. Some of the more successful, such as Shaykh Yusuf al-Qaradawi, combine multiple media-personal appearances, books (often based on the spoken word), pamphlets, audio and video cassettes, radio, television, satellite television and Internet- to reach a variety of audiences.

\section{The public sphere as 'shared anticipation'}

The transformations associated with the rise of modern nationstates, bureaucracies and capitalist sectors within societies are related to a phenomenon that can be termed an 'education into anticipation'. This notion builds on Norbert Elias' (2000 [1939]) concept of the 'civilizing process' and overlaps with the notion of habitus as 'a matrix of perceptions, appreciations, and actions', a 'generative principle of regulated improvisations that makes possible the achievement of infinitely diverse tasks' (Bourdieu I977: 78, 83). However, the notion of habitus downplays the importance of the 'externalities' of discourse in setting rules of communication and interaction (Calhoun I 992: 73-74). Dewey offers a more comprehensive approach, arguing that shared habits and practice, mediated by discourse accepted as authoritative, allow a community to build up a sense of expectation about others. Gellner ( I 995) discusses how the modern state inculcates the habits of the citizen and shapes common identities-through shared experiences such as military conscription, schooling with a common curriculum, and taxation. The public can be thought of as the orchestrated realm of the permissible.

Equally important are common forms of resistance to the state. Thus Iranian villagers, faced with the disruptions of the Shah's White Revolution, developed shared practices to deflect or indirectly defeat state intervention in their affairs (Goodell I 986). Iranian youth born since the I978-I979 revolution are also beginning to participate in a 'postIslamic' public space in which they increasingly ignore regime restrictions on dress, leisure activities, relations between the sexes, and other aspects of life (Khosrokhavar and Roy I 999: I 43-205). Throughout the 
Muslim-majority world, as elsewhere, students learn not only the formal elements of the curriculum in school, but also the hidden lessons of bureaucratic indifference, hierarchy, class, ethnicity and gender identity. In the diverse, rapidly changing conditions of modern society, the state cannot provide guidance from above to shape all activities. More complex ways of inculcating and negotiating background understandings are needed to provide the 'connecting tissue' of information, expression, and solidarity.

In drawing attention to the communicative and interconnected aspects of social life that we call the public sphere, Dewey shows how acts become public when their consequences, even if initiated in private, indirectly affect the welfare of many others (Dewey I 927: 13). For this reason, the state or the community also acts to regulate or to limit certain actions of individuals if these actions threaten the community. The public entails an awareness among members of a society that discrete acts have a general impact on others. Hence the sense of public is the means through which this perception of the consequences of actions is generalized. People are 'educated' into this perception, anticipating the consequences of one another's actions. This is the point at which Dewey's notion of the public and Elias' notion of the 'civilizing process'-despite their divergent theoretical concerns-converge. Shared anticipation is the condition of possibility of a public sphere.

The emergence of the public coincides here with the opening up of the circles of reciprocity and mutual obligations, which also allows for the crystallization of a notion of social welfare and general interest. The consolidated effect of the socialization that allows people to anticipate the consequences of their actions can also be called 'moral agency', a broader notion than citizenship.

Of course, media-mediated, mass forms of communication that are not face-to-face are also crucial to the modern public sphere. Schooling and television broadcasts (including interview programs and soap operas) contribute to developing a collective sense of anticipation and internalization of norms. These patterns of anticipation are crucial to debates on common interest, but they are not the whole story. Liberal political theory, as exemplified by Kant and Habermas, assumes that contributors to the public sphere are engaged in basically free exchanges of opinions unrestricted by considerations of status or authority. Dewey's approach requires no such idealism. For him, the public sphere is at once more dynamic-and more fragile. Speakers and their audiences take a variety of background information into account and engage in a great deal of miscommunication and misapprehension. 
In the context of modern, complex societies, shared standards of anticipation must still be based on ties that are perceived as local, even if these 'localities' - taking advantage of modern communications-are not local in a geographical sense. Even for the r 920s, Dewey ( 1927: 2 I6) called for a restoration of 'local communal life', a task perhaps technically easier today than in earlier eras. The public spheres of contemporary societies and polities are made up of highly diverse groups. They all possess a strong sense of local knowledge, but not always the same local knowledge, although they significantly overlap. Modern public spheres are constituted through a frail, overlapping consensus based on shared mechanisms of anticipation. In the Turkish case, for example, nationalists may say that loyalty to the nation transcends all other identities. Yet, as Bellér-Hann and Hann (200I: 22) explain, many other identities emerge from the 'continuous flow of social interaction'. National identity combines with 'identities of a more traditional sort, such as those linked to language, gender, family and religion, and with newer identities that people create in increasingly globalised marketplaces'. Moral agency does not necessarily operate with the same intensity or in the same way in all shared circles of consensus. For example, a media campaign to raise funds for relief work in Bosnia or Palestine, or to provide meat for the poor on Muslim feast days, entails different dimensions from a movement based primarily in a single locality.

Of the multiple modern public spheres, the nation-state claims primacy, prescribing models of homogeneous identity-formation and ritual constitution for the whole community. One key ritual, even in authoritarian states, is general elections. The complexity of social life, the modularity of identities, and the contest over primacy shows in the existence of 'warm' circles of community and obligation. Warm circles are trusting, familiar and open-ended. They demand loyalty and imply reciprocity. 'Cold' circles of community-those that are formal, distant and single-stranded-also make claims to loyalty and primacy, but in practice they are relegated to secondary importance or are ignored. What is distinctive about the modern public sphere is the rapidity with which cold circles of community can sometimes merge with warm ones, creating novel senses of community. Scheff (I990: 22) argues that there has been a paucity of systematic studies of bonds of communal solidarity, with the result that Durkheim's distinction between mechanical and organic solidarity-or for that matter the distinction between community and society - deflects attention away from the possibility that these two types of solidarity are often interwoven. The notion we develop here of shared social anticipations parallels Thomas Scheff's (I990: 30-3I) 
development of the notion of abduction, a concept derived from philosopher Charles Peirce (I839-I9I4). This is the process of shuttling back and forth between observation and imagination 'which enables participants to accomplish the incredibly complex process of understanding meanings in context'. Moreover, such understandings involve both emotional and intellectual attunement among participants in solidarity groups, maintaining social ties and bonds of identity and building trust through the 'reciprocal ratification' of feelings and actions (Scheff I 990: 7-8).

Inculcated and shared standards of anticipation, generated and transformed through habit and practice, are often conceived of in terms of a stable 'tradition' (Elias I 997: 67). In this form, they establish the cohesiveness of norms in modern societies. The reproduction and transmission of these norms always requires an endless capacity for creative adaptation. Nicolas Haddad, a major Egyptian reformer and 'protosociologist' of early twentieth century Egypt, reformulated the tradition of $a d a b$ ('manners') in terms of acquisition of the skills necessary for 'social commerce'-a notion that resonates with Elias' underlying idea of the civilizing process. Haddad maintained that, 'unlike other species, man's struggle for survival is associated specifically with two ideas: life expectancy (al-ajal al-madid) and quality of life (al-hazzal-sa'id, literally, 'good luck')'. These two ideas come together in the concept of the future (al-mustaqbal)' (Farag 200I: I09). This new sociology-paralleled for the Turkish context by Ziya Gökalp and for the Iranian context by Ahmad Kasravi (Parsi 2000: I33-I39)—was also a new program of education. Haddad's examples of how normativity works-through teaching anticipation-evokes Gellner's ( I 995) conception of building a 'modular self', a modern sense of responsible agency based on a distinction between different fields of social action and action within these fields.

The way a sense of public is built into social interactions varies considerably with social context and notions of personality, responsibility and justice inherited from older traditions. In the context of the contemporary nation-state, modern techniques of authority, persuasion and control must be taken into account. These may limit the construction of a genuinely 'modular' self. State techniques such as military conscription, policing practices, the perceived pervasiveness of informers, and modern schooling dramatically influence the sense of shared anticipations. In repressive regimes, this is done through persuading the public of the omnipresence of informers.

Less sinister forms of social control also abound. Discussion may often be 'channeled', so that the major media (radio, television and mass 
circulation newspapers) are carefully regulated in what is said and not said, while the 'little' media, such as books and magazines of more limited circulation, are given considerably more latitude for expression. Modern censors and state authorities often allow some open forums for discussion, knowing that these media fail effectively to reach the majority of the audience (Eickelman I999: 35). Moreover, not only the state, but private organizations and interest groups, seek to regulate and control their presentation of self in the public sphere (Jackall and Hirota 2000).

There are many forms of state, as Dewey says, but in most societies the modern state, whether authoritarian or liberal, is strong and pervasive, and there are continuing debates about the proper limits to state authority. The modern state says that it exercises censorship for the good of its citizens, and polices society for the same reason. The state, whether in Muslim-majority societies or in Europe, sets the stage and the rules of conduct. On the other hand, the state may be increasingly challenged or criticized. Such criticism may not always be effective and it may sometimes be dangerous, but most state authorities are increasingly aware that their current secrets or indiscretions, and those of the past, may be the subject of public commentary and discussion.

The existence of a modern nation-state, however, does not inevitably lead to an open public sphere in which the discipline of shared anticipations (only part of which emanates from the state) and the possibility of deliberation on public matters emerge together. For this to occur, other social actors are needed who have some degree of autonomy, who are not instruments of the state (although detractors may impute this role to them), and who communicate through available and effective forums and communications media. The mix of resources will vary. In Syria, it may be the salons of established businessmen and intellectuals, gatherings known to state authorities but tolerated because they are not mentioned in formal media (Al-Azm 2000). Other venues include the new media, audio and videocassettes, photocopied leaflets, as well coffee shops, mosques and church congregations. They may also include secret or 'non declared' associations. Just as secret lodges were important for the Enlightenment movement in Europe, organizations not formally declared to the state or reported to it often acquire a major significance. Sometimes the same people are involved in both kinds of activities. This was as much the case for French philosophes such as Denis Diderot and Muslim reformers such as Muhammad 'Abduh. In the end, however, not all authority ends up being absorbed into the public sphere. There is 
a constant tension between state and society over the space allowed for the public sphere.

\section{Solidarity and circles of communication in the modern public sphere}

Communications within 'warm' circles and the creation of public circuits of communication in wider, 'cold' public spheres do not mark two different social types of public. They are crosscurrents within the same societies and the same or overlapping public spheres. Consider, for example, Egyptian Islamic intellectual and media star Mustafa Mahmud (born I 92 I). His career, especially after he became identified with Islamic thought and practice, shows how expressive and informational transactions are linked to social solidarity in the public sphere (Salvatore 200I). Mahmud's particular role in the Egyptian public sphere has been to articulate the scholarly discourse of ulama with the needs and practices of wider groups, contributing to a 're-intellectualization' of Islam in an accessible vernacular form. Before becoming an Islamic intellectual in the I960s, he was a secularist. Following vigorous protests from some religious figures, state authority confiscated his book Allah wa-linsan ('God and man') in 1956 on the allegation that it spread atheistic and impious thoughts. By his account, he then began a journey in the search of truth that brought him 'from doubt to faith' (min al-shakk ila-l-iman), the title of one of his later best-sellers. He began his 'Islamic' career in the late i 960 s with the publication of a Quranic commentary (tafsir). Its popularity was due to the inclusion of both the vocabulary of the natural sciences (Mahmud was a medical doctor) and the vernacular of everyday experience. This blend of religion, science and common sense-and showing the consistency among them-proved a winning formula.

His public liked him because he helped them to identify Islam (against a wall of doubt elaborated by poorly understood but respected modern science) as a blueprint for social responsibility that transcended material and individual interests. By the early i 970s, Mahmud built up a successful television series, 'Science and Faith' (al-ilm wa-l-iman), founded his own mosque, and created a charitable medical association. These actions legitimized his public discourse because the publicprimarily Egyptians, but also Palestinians and Jordanians-knew that it was accompanied by concrete social acts.

Mahmud's rapid rise in popularity did not represent the ascendancy of 'lay' religious authority over that of the ulama. His ascent and the 
crucial support he received from the Shaykh al-Azhar of the time, 'Abd-al-Halim Mahmud, shows how much he still depended on an implicit association with traditional ulama. Nor did the Egyptian public see his style of media authority as radically alternative to that of the leading television preacher of the time, Shaykh Muhammad Mutawalli Sha'rawi (d. I 998). Mahmud's audience sees these two 'stars' as different in style but reinforcing one other. In Mahmud's heyday in the r 980 s and early i 990s, his public also listened to him in a different way to that of an earlier era. In an earlier period, Nasser spoke to audiences. Mahmud spoke with them. Families gathered in their living room to watch his program, so that he shared their domestic space. Invoking the masterdisciple relationship of Sufism, people who knew him only through television referred to him as 'their' shaykh, a claim made more vivid by knowledge of his charitable works. In his clinics, some patients expected to be treated by him (although he ceased practising medicine decades earlier) rather than by the regular clinic staff. Whereas public figures such Muhammad Shahrur and Sa'id Ramadan al-Buti of Syria represent opposing types with incompatible views, Sha'rawi and Mustafa Mahmud make more of a double billing of complementary personalities in Egypt.

The ability of some actors and messages to transform the 'cold' sphere into a 'warm' one, as Mustafa Mahmud successfully did, is characteristic of the modern era. This transformative ability is rapidly being accelerated by new interactive media such as the Internet and satellite television-often freed from many conventional state restrictions. The result is an intensified cross-cutting of messages. There has long been a de facto pluralism in the Muslim majority world, although sometimes masked by some groups and leaders asserting their leadership over the umma, the worldwide community of Muslims. Intensified communications have resulted in a sort of horizontal transnationalism of nonstate actors. This may be expressed in a concern for Muslim minorities, the boundaries of accommodation to non-Muslim majorities, and the permeability of the frontiers of Muslim thought and practice. The cross-cutting includes 'Western' and 'Muslim' circles of communication. The two circles often overlap and are mutually supportive. Debates over 'being Muslim' can be intensely local or follow lines of language. They can also be regional or even global, as in a Kuwaiti newspaper debate over whether women should participate in the 1995 Beijing World Conference on women (Shahrur I 998). In these discussions and practices, 'being Muslim' is never an exclusive identity, for one also has identities of family, language, nation, region, gender and 
others that make identities situational and which also require pragmatic compromise and accommodation.

In modern societies, including authoritarian ones, there are other actors besides the state. For example, engaged Muslims who have the means to do so use media as well as the ability to support collective projects for the public good, creating vehicles for teaching others in words and in deeds how to be a good Muslim. This consciousness of media power and the partial accessibility of some media even in authoritarian sociopolitical contexts also provides alternatives to thinking of Islamic action in immediate political terms. It can equally mean contributing to the construction of an Islamically informed public as a more realistic goal than the establishment of a local or worldwide Islamic state (Yasin I 999: 75-83). This option also corresponds to a Dewey-like gradualistic view (in Arabic, tadarrujan), which is also a pragmatic means of accommodating to authoritarian states or militant secularism.

\section{Conclusion: whither modularity?}

Modern identities are basically modular, as Gellner (I 995) and others assert. They are often inculcated through formal education and state practices, but they always have to be socially sustained and are subject to change over time. Modularity is never self-sufficient and self-sustaining. There are cultural differences in how a public reason is distilled and legitimized out of these overlapping 'ties that bind' and how they interact with the 'firmest tie', as Islam is called in the Quran (2: 256;3 I: 22). On the other hand, in seeking to understand the link between the public sphere and Muslim identities, we see more than a politics of 'identity', of almost optional affinities, as is the case in the entitlement politics of certain US and European contexts. A contemporary Islamic public encompasses the publishing business (magazines, books, audiocassettes and their networks of distribution), reading groups, relief associations, solidarity networks and political movements, and-of particular significance-the mosque and the collective Friday prayer and sermon. These media and sites combine in a multitude of ways. This Muslim public is grounded in practices that emerge through the complex process of ingraining of Muslim traditions into modern social life. Based on a study of efforts in independent Pakistan to implement Islamic law (shari'a), Masud (200I) indicates how this supposedly fixed tradition, like modernity itself, is a process of discourse and practice, not fixed in content other than the ideological claim that it is fixed. 
Culture, however, must not be understood in the older sense of fixed and static practices but as contested, loosely bounded and emerging. Eisenstadt's (2000) notion of 'multiple modernities' is one way of accounting for these different trajectories and relating them to the idea of the public sphere.

One reason for the importance of seeing continuities between the public spheres of the past and the present is to foreground the element of shared standards of anticipation that make public spheres-and in some cases, democracy-work. This essay suggests some points of departure for understanding a variety of historical trajectories and background cultural understandings that can shape public spheres. It also suggests ways of accommodating some of the European-centered main currents of social thought to the vital way in which religious belief and practice continues to play a dynamic, and often constructive, role in shaping the modern public sphere.

\section{$R E F E R E N C E S$}

Al-Azm, Sadik J. (2000), The View from Damascus, New York Review of Books 47, no. Io (June I 5), 70-77.

Andezian, Sossie (2001), Expériences $d u$ divin dans l'Algérie contemporaine: Adeptes des saints de la région de Tlemcen (Paris: CNRS Éditions).

Bellér-Hann, Ildikó, and Chris Hann (200I), Turkish Region (Oxford: James Currey, and Santa Fe: School of American Research Press).

Benthall, Jonathan (2000), Civil Society's Need for De-deconstruction, Anthropology Today 6, no. 2, I-2.

Bourdieu, Pierre (1 977), Outline of a Theory of Practice (New York: Cambridge University Press).

Calhoun, Craig (I 992), 'Introduction,' in Habermas and the Public Sphere (Cambridge, MA: MIT Press), I-48.

Casanova, José (1994), Public Religions in the Modern World (Chicago: University of Chicago Press).

Chakrabarti, Dipesh (2000), Provincializing Europe: Postcolonial Thought and Historical Difference (Princeton: Princeton University Press).

CoRnell, Vincent J. (1998), Realm of the
Saint: Power and Authority in Moroccan Sufism (Austin, TX: University of Texas Press).

DeEs, Lara (forthcoming), 'Doing good, like Sayyida Zeinab': Community welfare and Shi'I Islamic social mobilization in the southern suburbs of Beirut. Florence, 3 rd Mediterranean Social and Political Research Meeting, EUI, 20-24 March 2002.

Dennerlein, Bettina (200I), Legitimate Bounds and Bound Legitimacy: The Act of Allegiance to the Ruler (Bai $a$ ) in Nineteenth Century Morocco, Die Welt des Islams 4I, no. 3 .

Dewey, John (1927), The Public and Its Problems (New York: Henry Holt).

Duben, Alan, and Cem Behar (i99i), Istanbul Households: Marriage, Family, and Fertility, I880-I940 (Cambridge: Cambridge University Press).

Eickelman, Dale F. (I992), Mass Higher Education and the Religious Imagination in Contemporary Arab Societies, American Ethnologist 19 , no. 4 (November), 643-655.

- (r999), Communication and Control in the Middle East: Communication and Its Discontents, in New Media and The Muslim World: The Emerging Public Sphere, Dale F. 


\section{D.F. EICKELMAN \& A. SALVATORE}

Eickelman and Jon W. Anderson (eds) (Bloomington: Indiana University Press), 29-40.

-, and Jon W. Anderson (i 999), Redefining Muslim Publics, in New Media and The Muslim World: The Emerging Public Sphere, Dale F. Eickelman and Jon W. Anderson (eds) (Bloomington: Indiana University Press), I-I 8.

Eisenstadt, Shmuel N. (2000), Fundamentalist Movements in the Framework of Multiple Modernities, in Between Europe and Islam: Shaping Modernity in a Transcultural Space, Almut HöFERT and Armando Salvatore (eds) (Brussels, Berlin, and Oxford: Presses Interuniversitaires EuropéennesPeter Lang), I 75-I 96

Elias, Norbert (1997), The Germans: Power Struggles and the Development of Habitus in the Nineteenth and Twentieth Centuries, translated from the German by Eric Dunning and Stephen Mennell (Boston: Polity Press).

- (2000 [orig. 1939]), The Civilizing Process, rev. ed. (Oxford: Blackwell).

FARAG, Iman (200I), Private Lives, Public Affairs. The Uses of Adab, in Muslim Traditions and Modern Techniques of Power, Yearbook of the Sociology of Islam (ed.) Armando Salvatore (Hamburg: Lit Verlag, and New Brunswick: Transaction Publishers), 93-I 20.

Gasper, Michael (200I), Abdallah Nadim, Islamic Reform, and 'Ignorant' Peasants: State-Building in Egypt? in Muslim Traditions and Modern Techniques of Power, Yearbook of the Sociology of Islam (ed.) Armando SalvaTORE (Hamburg: Lit Verlag, and New Brunswick: Transaction Publishers), 75-92.

Geertz, Clifford (I 983 [orig. I 977]), Centers, Kings, and Charisma: Reflections on the Symbolics of Power, Local Knowledge (New York: Basic Books), I 2 I-I 46.

Gellner, Ernest (I994), Conditions of Liberty (London: Allen Lane).

- (I995), The Importance of Being Modular, in Civil Society: Theory, History, Comparison (ed.) John Hall (Boston: Polity Press), 32-55.

Gonzalez-Quijano, Yves (1998), Les gens du livre: Édition et champ intellectuel dans l'Égypte républicaine (Paris: CNRS Éditions).

Goodell, Grace E. (1986), The Elementary Structures of Political Life: Rural Development in Pahlevi Iran (New York: Oxford University Press).

Gran, Peter (1979), Islamic Roots of Capitalism. Egypt, I760-I840 (Syracuse, NY: Syracuse University Press).
Habermas, Jürgen (I992), Faktizität und Geltung (Frankfurt: Suhrkamp).

- (200I), The Public Sphere: An Encyclopedia Article, in Media and Cultural Studies: Keyworks (ed.) Meenakshi Gigi Durham and Douglas M. Kellner (Oxford: Blackwell), I02-107.

Hammoudi, Abdellah (I997), Master and Disciple: The Cultural Foundations of Moroccan Authoritarianism (Chicago: University of Chicago Press).

HofHeinz, Albrecht (I992-I993), Der Scheich im Über-Ich, oder Haben Muslime ein Gewissen? Zum Prozess der Verinnerlichung schriftislamischer Normen in Suakin im frühen i 9. Jahrhundert, Wuquf, no. 7-8, 46I48 I.

Jackall, Robert, and Janice M. Нirota (2000), Image Makers: Advertising, Public Relations, and the Ethos of Advocacy (Chicago: University of Chicago Press).

Kamali, Masoud (200I), Civil Society and Islam: A Sociological Perspective, Archives européenes de sociologie, XLII, 457-482.

Keddie, Nikki R. (I 994), The Revolt of Islam, I 700 to I 993: Comparative Considerations and Relations to Imperialism, Comparative Studies in Society and History 36, 463-487.

Khosrokhavar, Farhad and Olivier Roy, Iran: comment sortir d'une révolution religieuse (Paris: Seuil).

Levtzion, Nehemiah (2002), The Dynamics of Sufi Brotherhoods, in The Public Sphere in Muslim Societies (ed.) Miriam Hoexter, Shmuel N. Eisenstadt, and Nehemiah Levtzion (Albany: State University of New York Press), I09-ı I 8.

Masud, M. Khalid (200I), Social Constructions of Shari'a in Pakistan, paper presented at the 200 I von Humboldt Foundation for Younger Scholars, 'Public Spheres and Muslim Identities' (Berlin), July I 7.

McQuail, Denis (1992), Media Performance: Media Communication and the Public Interest (London: Sage).

Meeker, Michael E. (2002), A Nation of Empire: The Modernist Legacy of Public Life in a Turkish Province (Berkeley and Los Angeles: University of California Press).

PARSI, Rouzbeh (2000), Reforming Society: Intellectuals and Nation-Building in Turkey and Iran, in Between Europe and Islam: Shaping Modernity in a Transcultural Space (ed.) Almut HöFert and Armando Salvatore (Brussels, Berlin and Oxford: Presses Interuniversitaires Européennes-Peter Lang), I09-I 40. 
Reichmuth, Stefan (i996), Education and the Growth of Religious Associations among Yoruba Muslims-The Ansar-ud-Deen Society of Nigeria, Fournal of Religion in Africa 26, no. 4, 365-405.

- (2000), 'Netzwerk' und 'Weltsystem': Konzepte zur neuzeitlichen 'Islamischen Welt' und ihrer Transformation, Saeculum 5 I, no. 2, 267-293.

Robinson, Francis (1993), Technology and Religious Change: Islam and the Impact of Print, Modern Asian Studies 27, no. I, 229-25 I.

Rouadjia, Ahmed (1990), Les frères et la mosquée: Enquête sur le mouvement islamiste en Algérie (Paris: Karthala).

Salvatore, Armando (1997), Islam and the Political Discourse of Modernity (Reading: Ithaca Press).

- (2000), The Islamic Reform Project in the Emerging Public Sphere: The (Meta)normative Redefinition of shari'a, in Between Europe and Islam: Shaping Modernity in a Transcultural Space (ed.) Almut HöfERT and Armando Salvatore (Brussels, Berlin, and Oxford: Presses Interuniversitaires Européennes-Peter Lang), 89- г 8 .

- (200I), Mustafa Mahmud: a Paradigm of Public Islamic Entrepreneurship?, in Muslim Traditions and Modern Techniques of Power, Yearbook of the Sociology of Islam (ed.) Armando Salvatore (Hamburg: Lit Verlag; New Brunswick, NJ, and London: Transaction Publishers), 2 I I-223.

Scheff, Thomas J. (I 990), Microsociology: Discourse, Emotion, and Social Structure (Chicago: University of Chicago Press).

Shahrur, Muhammad (I 998 [orig. I995]), Islam and the 1995 Beijing World Conference on Women, in Liberal Islam: A Sourcebook (ed.) Charles Kurzman (New York: Oxford University Press), I39-I 42.

TAPPER, Richard (I990), Anthropologists, Historians, and Tribespeople on Tribe and State Formation in the Middle East, in Tribes and State Formation in the Middle East (ed.) Philip S. Khoury and Joseph Kostiner (Berkeley and Los Angeles: University of California Press), 48-73.

TAYLOR, Charles (I 993), Modernity and the Rise of the Public Sphere, The Tanner Lectures on Human Values (Salt Lake City: University of Utah Press), vol. I 4, 203-26o.

Tenet, George J. (200I), 'Worldwide Threat 200 I: National Security in a Changing World,' statement to the Senate Select Committee on Intelligence, February 7. Available at http: //www.cia.gov/cia/public-affairs/kspeeches/UNCLASWWT-0207200I.html.

Walker, Edward S. (200I), The New US Administration's Middle East Policy Speech, Middle East Economic Survey 44, no. 26 (June 25). Available at http: //www.mees.com/ news/a44n26dor.htm.

Weber, Max (1920), Gesammelte Aufsätze zur Religionssoziologie (Tübingen: J.C.B. Mohr).

White, Jenny B. (I 999), Amplifying Trust: Community and Communication in Turkey, New Media in the Muslim World: The Emerging Public Sphere (ed.) Dale F. Eickelman and Jon W. Anderson (Bloomington: Indiana University Press), I 62-I 79 .

YAsIN, al-Sayyid (I 999), Qadaya al-mu'asira wa al-khilafa: hiwar 'almani-Islami [Current affairs and the caliphate: a secular-Islamic dialogue] (Cairo: Mirat li al-nashr wama'lumat). 